\title{
Selection of Root-Knot Nematod Resistance in Inbred Tomato Lines Using CAPS Molecular Markers
}

\author{
Zafer Seçgin ${ }^{1}$, Yunus Emre Arvas ${ }^{2}$, Simon Peter Ssendawula ${ }^{3}$, Yılmaz Kaya ${ }^{1 *}$
}

\begin{abstract}
Abstact: Tomato root-knot nematode, is one of the most important disease agents in tomatoes (Solanum lycopersicum). A practical and effective method for controlling this disease is by means of tomato genotypes with resistance genes against this disease. Tomato plants are offered resistance to root-knot nematode by Mi gene. Phenotypically observing genetic lines in terrestrial conditions is difficult and time consuming due to concerns about the transfer of this agent to other plants and their stability. By using the molecular markers related to resistance genes, this problem can be avoided and the selection efficiency can be increased. In this project, 34 inbred lines were tested using 1 CAPS marker associated with Mi gene, resistant and susceptible genotypes were identified. In the study, 34 genotypes were not found to be homozygous resistant (MI / MI) genotypes whereas 7 genotypes were found to be heterozygous resistant (MI / mi) and 27 genotypes ( $\mathrm{mi} / \mathrm{mi}$ )homozygous susceptible. As a result of this study, root-knot nematode is the basis for developing resistant varieties.

Key words: Tomato, Mi gene, CAPS
\end{abstract}

\section{Introduction}

Tomato (Solanum lycopersicum L.) is one of the most important horticultural crops worldwide [1] and a good source of vitamins A and C [2] widely grown around the world. According to the figures of the year 2014, tomatoes produced in the world with 5,023,810 hectares of land 170,750,767 tons were produced in 319,109 hectares and 11,850,000 tons in Turkey. With this amount, Turkey, comes in the 4th place after China and the USA.

\footnotetext{
${ }^{1}$ Ondokuz Mayıs University, Faculty of Agriculture, Department of Agricultural Biotechnology, Samsun, Turkey

2 Yildiz Technical University, Graduate School of Sciences, Department of Molecular Biology and Genetics, Samsun, Turkey

${ }^{3}$ Ondokuz Mayıs University, Graduate School of Sciences, Department of Agricultural Biotechnology, Samsun, Turkey

*Corresponding Author: yilmaz.kaya@ omu.edu.tr , Tel: +903623121919-1362
} 
Root-knot nematodes (RKNs), Meloidogyne spp., are considered to be the most damaging nematode group in the world as they cause high yield losses to most cultivated plant species in subtropical and tropical regions (Chen [3, 4]. RKNs, Meloidogyne spp., are obligate, sedentary endoparasites of many plant species [5]. Their potential host range encompasses more than 3000 plant species [6]. The most economically important species are M. arenaria Chitwood, M. javanica Chitwood and M. incognita Chitwood. In Turkey, the Mediterranean region is the most important for protected and open field vegetables. $M$. arenaria, $M$. javanica and $M$. incognita are among the major economic problems facing crop production in this region (Elekcioglu [7, 8].

The tomato crop is seriously affected by over 200 diseases caused by pathogenic fungi, bacteria, viruses and nematodes therefore a major goal of modern tomato breeding programs is the development of cultivars with improved disease resistance [9]. Most of the current management strategies to control RKNs rely on genetic resistance, cultural control and nematicide application (Chen $[3,10]$. The most practical and effective method to control root-knot nematode disease is host resistance against this disease because other applications such as the use of nematicides, the concerns about environmental and human health risks, and the high cost limits the use of nematists $[6,10,11]$.

However, currently only the Mi gene confers resistance against root-knot nematodes and it was introgressed to Lycopersicon esculentum from its wild relative L. Peruvicanum in the early 1940s by embryo rescue [12]. In tomato, resistance to RKN is controlled by a single dominant gene designated as Mi-1 gene. Nowadays Mi-1 gene is a single source resistance to root-knot nematodes in cultivated cultured tomatoes. The Mi-1 gene confers resistance to three species of RKN, Meloidogyne incognita, Meloidogyne javanica and Meloidogyne arenaria (Roberts [13-15]. This tomato gene is mapped on 6. Chromosome. However, Mi-1 mediated resistance to RKNs can lose efficacy when soil temperatures are higher than $28^{\circ} \mathrm{C}$ and can also be hampered by the occurrence of resistance-breaking populations [16].

After identifying the genes found in the genomic pathway associated with resistance to a disease, there are various methods for monitoring these genes, such as molecular markers. Genomic approaches can be enhanced by the identification of genes for resistance to disease and the identification of markers associated with these genes. 


\section{Material and Methods}

In this study, 34 inbred lines of tomato (Lycopersicon esculentum Mill.) were used as plant material. Tomato seeds were germinated in a 1: 1 mixture of peat perlite in violel. The genomic DNA extraction was performed according to the manufacturer's protocol instructions (QIAGEN, Hilden Germany) using $100 \mathrm{mg}$ tomato leaf tissue as starting material. A final volume of $50 \mu 1$ Nuclease-free water was used to eluate DNA. The DNA concentration was determined by the absorbance at 230, 260 and $280 \mathrm{~nm}$, using the NanoDrop 2000 spectrophotometer (Thermo Fisher Scientific, Waltham, USD). And the final concentration of each sample was set at $10 \mathrm{ng} \mu \mathrm{l}-1$.

In this study, PCR-based CAPS marker was used as DNA marker. Each PCR reaction contained a total of $4 \mu \mathrm{l}$ master $\operatorname{mix}(1.5 \mathrm{mM} \mathrm{MgCl} 2,0.2 \mathrm{mM}$ dNTPs, 0.5 Units Taq DNA polymerase and 10x PCR buffer) (Rosebio), $4 \mu \mathrm{l}$ DNA (10 ng $\mu \mathrm{l}-1), 1 \mu \mathrm{l}$ primers Forward and reverse primers (Centromere DNA Technologies) and $10 \mu 1$ of nuclease-free water. PCR amplification was performed on a Biorad T100 thermal cycler according to the standard PCR method. Primer sequences used in PCR studies are given in Table 1. PCR conditions for Rex Primer were as follows: 1 cycle at $95^{\circ} \mathrm{C}$ for 3 minutes, 30 cycles at $95^{\circ} \mathrm{C}, 30$ seconds at $52^{\circ} \mathrm{C}, 30$ cycles at $72^{\circ} \mathrm{C}, 35$ cycles at $95^{\circ} \mathrm{C}, 5$ minutes. At the end of PCR amplification, PCR products were separated on a 1\% (W/V) agarose gel and $0.5 \mu \mathrm{g} \mathrm{ml}-1$ ethidium bromide was added to visualize DNA bands. The sizes of the DNA fragments were determined using a 50 bp DNA ladder (Biolab). In order to confirm PCR amplification and gel electrophoresis results, the study was repeated at least twice.

PCR products were cut with Taq 1 enzyme to distinguish genotypes as susceptible or resistant. In total, $7.5 \mu \mathrm{l}$ of PCR product was added, and $0.5 \mu 1$ of Taq 1 enzyme (BIOWORLD $4000 \mathrm{U} / \mathrm{ml}$ ) and $1 \mu \mathrm{l}$ of Cut start buffer were added and the PCR was allowed to stand at $65^{\circ} \mathrm{C}$ for 15 minutes in thermal cycler. After cleavage was complete, the fragments were run on $2 \%$ agarose gel electrophoresis at 80 volts for 3 hours. After gel electrophoresis, PCR products were imaged using a Syngene gel imaging device.

Table1. Root-Knot Nematode Related iCAPS markers and their properties

\begin{tabular}{|c|c|c|c|c|c|}
\hline $\begin{array}{c}\text { Primer } \\
\text { Name }\end{array}$ & Primer sequence & $\begin{array}{c}\text { Marker } \\
\text { Type }\end{array}$ & $\begin{array}{c}\text { Resistance } \\
\text { band }\end{array}$ & $\begin{array}{c}\text { Susceptability } \\
\text { band }\end{array}$ & Reference \\
\hline
\end{tabular}




\begin{tabular}{|c|l|l|l|l|l|}
\hline Rex-F & $\begin{array}{l}\text { (5'-TCGGAGCCTTGGTCTGAATT- } \\
3^{\prime}\end{array}$ & SCAR & & & [17] \\
\hline Rex-R & $\begin{array}{l}\text { 5'-GCCAGAGATGATTCGTGAGA- } \\
\mathrm{T}\end{array}$ & SCAR & & & \\
\hline
\end{tabular}

\section{Results}

In the study, a total of 34 inbred tomato lines were identified to contain Mi gene, which genetically provides resistance to root-knot Nematode. In CAPS marker studies with Rex 1 primers, PCR products produced a single band at a size of $750 \mathrm{bp}$ in 34 tomato lines used in the experiment when electrophoresed prior to cutting with Taq1 enzyme (Fig1 and Fig2).

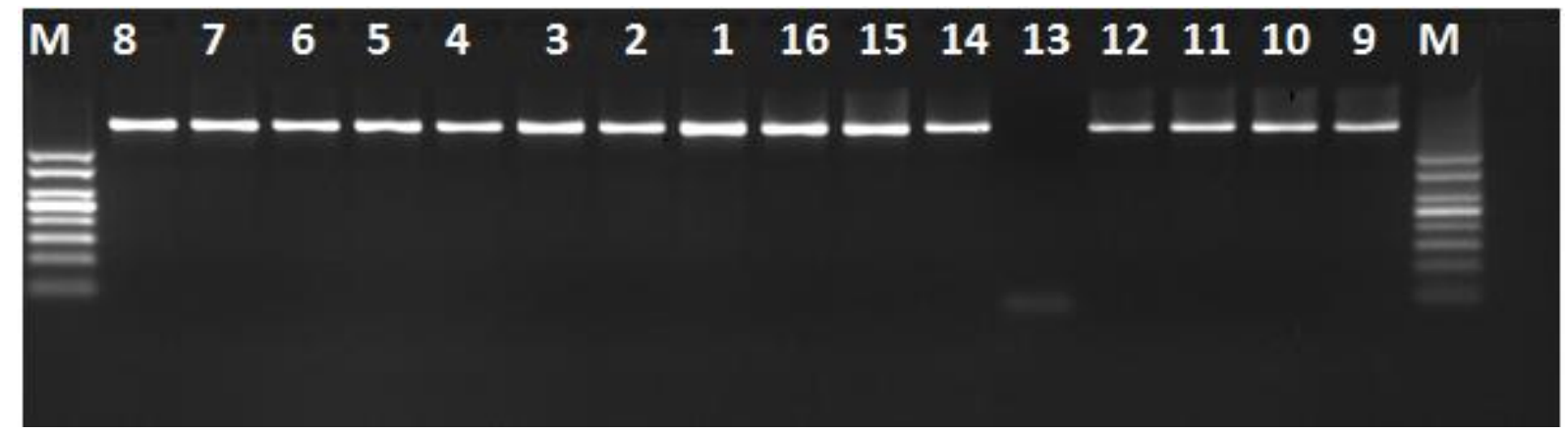

Fig 1. Amplification of tomato genotypes and CAPS markör by PCR in each genotype using the isolated DNA template. M: DNA marker (Biolab, $50 \mathrm{bp}$ ), 1 to 16 tomato genotype

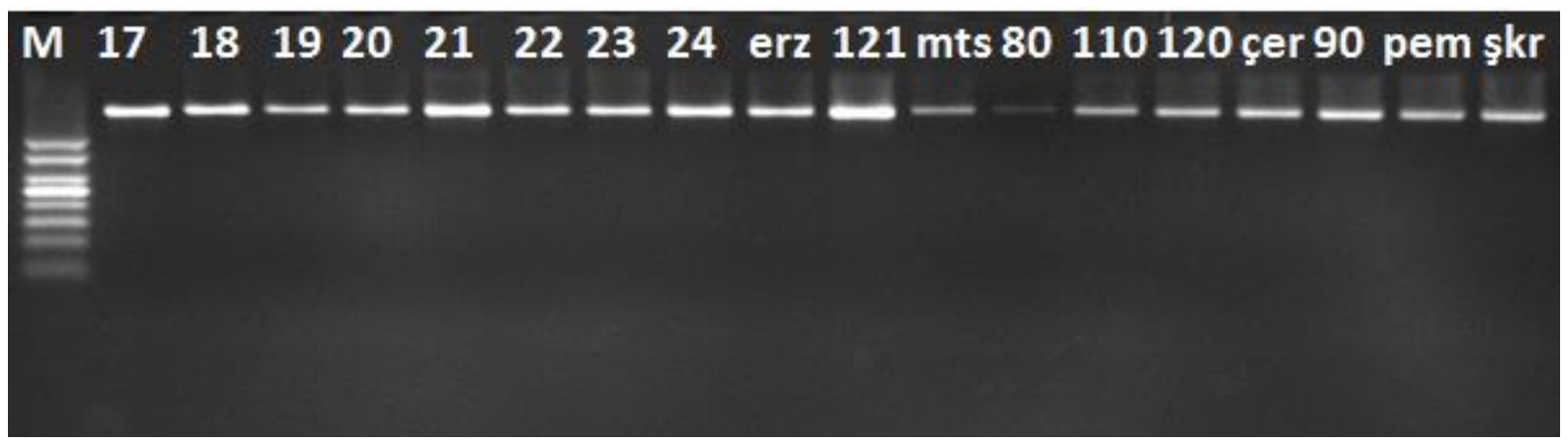

Fig 2. Amplification of tomato genotypes and CAPS markör by PCR in each genotype using the isolated DNA template. M: DNA marker (Biolab, $50 \mathrm{bp}$ ), 1 to şkr tomato genotype

PCR products with Rex primer resulted in 3 band profiles of 750, 570 and $160 \mathrm{bp}$ after cutting with Taq1 enzyme (Fig. 3 and Fig. 4). The genotypes giving a single band at the size of $750 \mathrm{bp}$ are homozygote-resistant ( $\mathrm{mi} / \mathrm{mi}$ ), heterozygous for all three bands (Mi / mi), homozygous for genotypes giving 570 and 160 bp band. (Mi / Mi) (Williamson, Ho 
et al., 1994, Duca, Port et al., 2012). As shown in Fig. 3 and Fig. 4, 34 genotypes produced mostly sensitive 750 bp fragments, while 1 genotype fragment was obtained and 7 gentipts produced $750 \mathrm{bp}, 570 \mathrm{bp}$ and $160 \mathrm{bp}$ fragments. 15, 16, 20, 120, 110, 121, 90 were heterozygous, while other genotypes were susceptible. With this marker, the identification of homozygous and heterozygous resistant and susceptible tomato genotypes has been successfully accomplished. The results of these studies are similar in literature. The gel images obtained are shown in Fig. 3 and Fig.

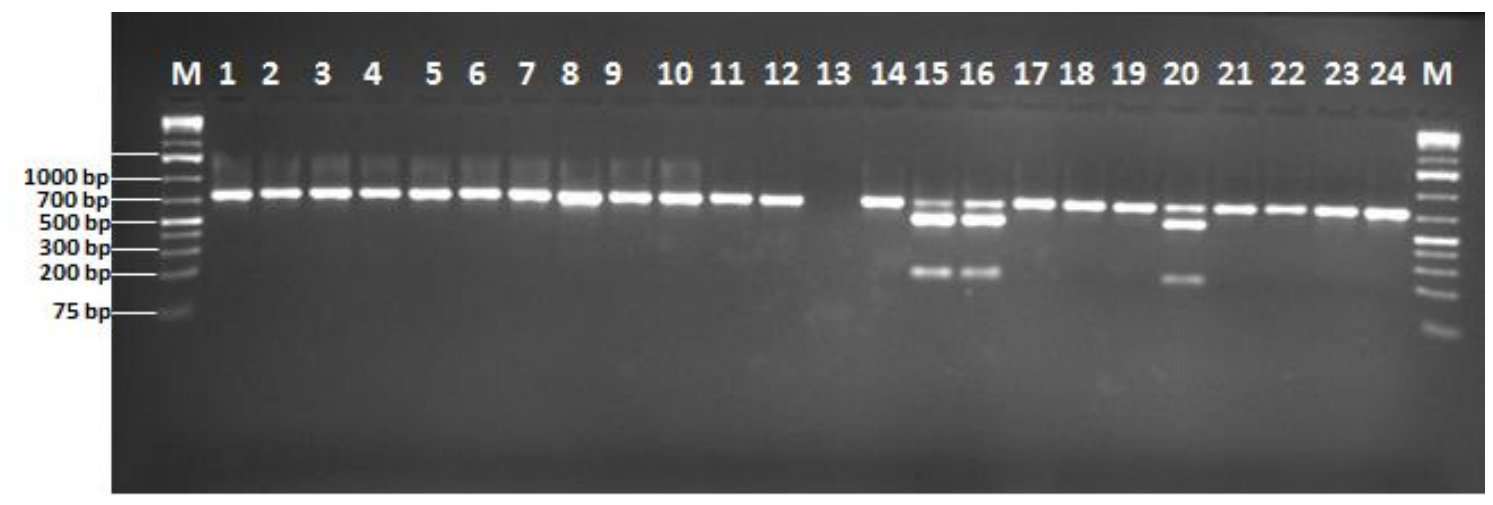

Fig. 3. Agarose gel image of $2 \%$ of Taq 1 enzyme cut-off results of tomato genotypes

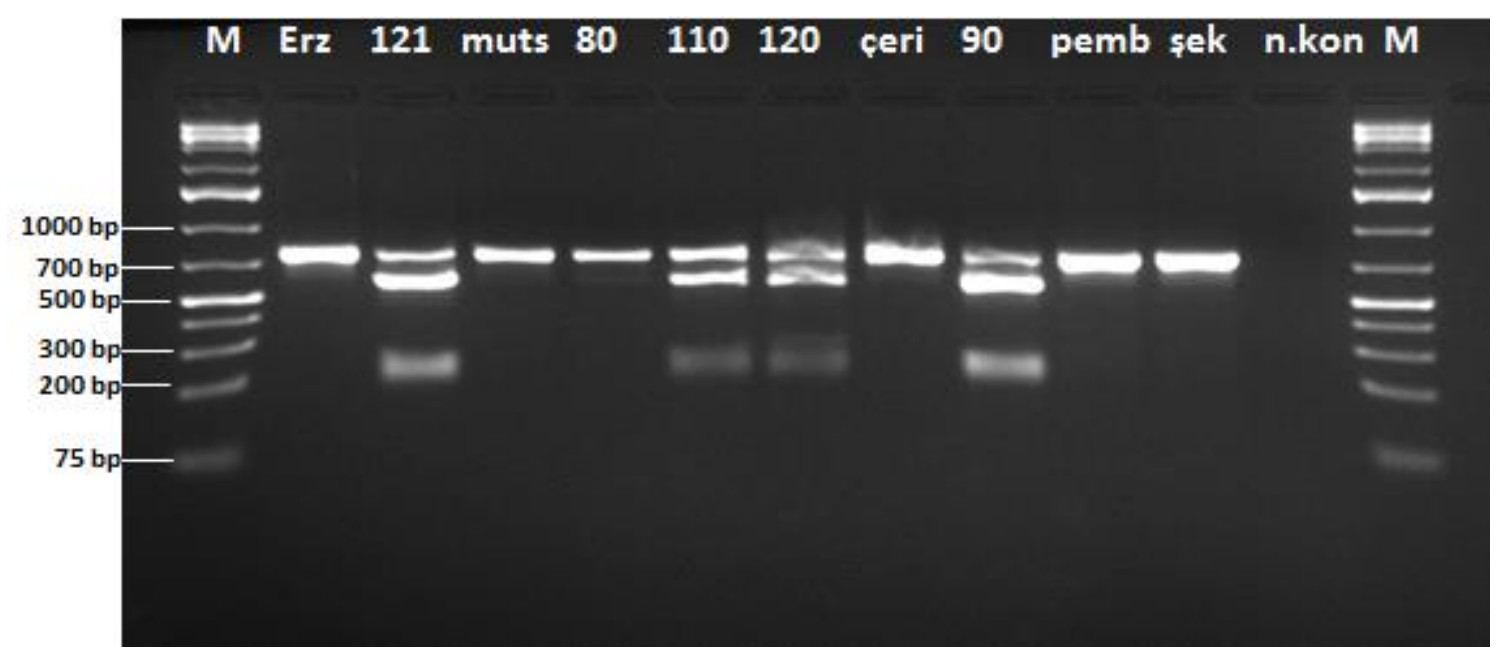

Fig. 4 Agarose gel image of $2 \%$ of Taq 1 enzyme cut-off results of tomato genotypes

\section{Discussion and Conclusions}

In disease control, the use of plants resistant to diseases is preferred due to the environmental risks of chemical combat methods. The tomato gene Mi-1 confers 
resistance to several of the most damaging root-knot nematode species and is widely deployed for nematode control [5]

Molecular markers have many applications in plant breeding and are commonly used to improve resistant varieties. Therefore, the development of confident molecular markers for resistance genes could be advantageous for rapid screening of breeding lines. Reliable molecular markers linked to Mi-1 gene have been developed in tomato because of difficulties in testing for RKNs.

These root knots alter the uptake of water and nutrients and interfere with the translocation of minerals and photosynthates in the host resulting in plants with poor yield, stunted growth, wilting, and susceptibility to other pathogens. Selection with assistance of Molecular markers does not only improve the efficiency of selecting resistant plants but also enhances efforts to combine nematode resistance in tomatoes.

\section{References}

1. Andolfo, G., et al., Genome-wide identification and analysis of candidate genes for disease resistance in tomato. Molecular breeding, 2014. 33(1): p. 227-233.

2. Mwesige, R., A. Seid, and W. Wesemael, Root-knot nematodes on tomatoes in Kyenjojo and Masaka districts in Uganda. African Journal of Agricultural Research, 2016. 11(38): p. 3598-3606.

3. Chen, R.G., et al., Functional Characterization of Mi, a root-knot nematode resistance gene from tomato (Lycopersicon esculentum L.). Journal of Integrative Plant Biology, 2006. 48(12): p. 1458-1465.

4. Devran, Z., et al., Comparison of PCR-based molecular markers for identification of Mi gene. Acta Agriculturae Scandinavica, Section B-Soil \& Plant Science, 2013. 63(5): p. 395-402.

5. Gleason, C.A., Q.L. Liu, and V.M. Williamson, Silencing a candidate nematode effector gene corresponding to the tomato resistance gene Mi-1 leads to acquisition of virulence. Molecular Plant-Microbe Interactions, 2008. 21(5): p. 576-585.

6. Devran, Z. and İ.H. Elekçioğlu, The Screening of F_2 Plants for the Root-Knot Nematode Resistance Gene, Mi by PCR in Tomato. Turkish Journal of Agriculture and Forestry, 2004. 28(4): p. 253-257.

7. Elekcioglu, I., et al., Plant parasitic nematodes in the east Mediterranean region of Turkey. Nematologia Mediterranea, 1994. 22(1): p. 59-63.

8. Elekçioğlu, İ. and N. Uygun. Occurrence and distribution of plant parasitic nematodes in cash crop in eastern Mediterranean Region of Türkiye. in Proc. of 9th Congress of the Mediterranean Phytopathological Union-Kuşadası-Aydın-Türkiye. 1994. 
9. Duca, M., et al., THE SCREENING OF SEVERAL MOLDAVIAN TOMATO CULTIVARS FOR IDENTIFICATION OF MI-NEMATODE RESISTANCE GENE. Analele Stiintifice ale Universitatii" Al. I. Cuza" din Iasi, 2012. 58(1): p. 5.

10. Molinari, S. and N. Baser, Induction of resistance to root-knot nematodes by SAR elicitors in tomato. Crop Protection, 2010. 29(11): p. 1354-1362.

11. Dhall, R., Breeding for biotic stresses resistance in vegetable crops: a review. J. Crop Sci. Technol, 2015. 4: p. 13-27.

12. Smith, P.G. Embryo culture of a tomato species hybrid. in Proc. Amer. Soc. Hort. Sci. 1944.

13. Roberts, P. and I. Thomason, Variability in reproduction of isolates of Meloidogyne incognita and Meloidogyne javanica on resistant tomato genotypes. Plant disease (USA), 1986.

14. Tzortzakakis, E.A., et al., Occurrence of resistance-breaking populations of root-knot nematodes on tomato in Greece. European Journal of Plant Pathology, 2005. 113(1): p. 101-105.

15. Guan, T., et al., Resistance-breaking population of Meloidogyne incognita utilizes plant peroxidase to scavenge reactive oxygen species, thereby promoting parasitism on tomato carrying Mi-1 gene. Biochemical and biophysical research communications, 2017. 482(1): p. 1-7.

16. Ammati, M., I. Thomason, and H. McKinney, Retention of resistance to Meloidogyne incognita in Lycopersicon genotypes at high soil temperature. Journal of Nematology, 1986. 18(4): p. 491.

17. Williamson, V., et al., A PCR-based marker tightly linked to the nematode resistance gene, Mi, in tomato. Theoretical and Applied Genetics, 1994. 87(7): p. 757-763. 